Article

\title{
Lacanian Perspectives on Love
}

\section{Darlene Demandante}

\begin{abstract}
This paper is an attempt to discuss the psychoanalyst/ philosopher Jacques Lacan's notion of love. I took into consideration his foundations in psychoanalysis and proceeded to his philosophical views on love as belonging to the imaginary register, that is, love for what the subject imagines as existing in the other, and love as belonging to the symbolic register, that which is articulated in speech. Finally, it argues that for Lacan, the essence of love is not that of wholeness and harmony but of difference.
\end{abstract}

Keywords: Lacan, love, transference, imaginary

\section{Lacan on the Problem of Love}

7 he problem of love is universal, such that it never ceases to baffle even the minds of the philosophers and scholars of philosophy. In fact, this problem is one of the most abused topics within and also outside of the intellectual discourse. ${ }^{1}$ Love has in one way or another confounded and continues to confound human beings in certain ways within and beyond the bounds of reason.

The classical humanist and essentialist definition of love has centered love in the free will of the human person. Such definitions convey the existence of two basic elements which comprise love, the subject who is the lover and an other who or which is the object or the subject of the love of the lover. ${ }^{2}$ The lover moves towards the very object of his love.

${ }^{1}$ Jacques Lacan in his Seminar XX: Encore, said "People have been talking about nothing else but love for a long time. Need I emphasize the fact that it is at the very heart of philosophical discourse?" Following this statement is his claim that this being the case should make one suspicious about the reality behind love. See Jacques Lacan, Seminar XX: Encore, On Feminine Sexuality The Limits of Love and Knowledge, trans. by Bruce Fink, (New York and London: W.W. Norton and Company, 1998). 39. Henceforth will be referred to as Seminar XX.

2 Philosophers often define love in relation to the other. For instance, Plato defines love as the possession of the other or the union with a split partner or a soul mate. Immanuel Kant, on the other hand, states that love is the persuasion of the other for his own end. St. Thomas Aquinas says that to love is to will the good of the beloved, while for Sartre, to love is

(C) 2014 Darlene Demandante

http://www.kritike.org/journal/issue 14/demandante june2014.pdf

ISSN 1908-7330

$(\mathrm{cc}) \mathrm{BY}$-NC 
For instance, people often speak of the one. The one represents the romanticized notion of the object of love. This one may be another person, thought to be the other half of one's soul who is yet to be found somewhere in life's journey, ${ }^{3}$ an object or the fulfillment of a dream. A person who loves expects to be united with the object of his love by being loved in return. Thus, he lives his life fueled by the desire ${ }^{4}$ for the other-the one.

However, there seems to be something lacking in these ideas of love. Why is it that many people do not agree with a single definition of love? Why is it that sadists cannot help but show their love through violence? Why do Christians "love their neighbor" while to some this seems pointless? Why are there people who kill for love and people who willingly lay their lives in the name of love? In other words, it seems that inasmuch as it is universal, love is clouded by particular experiences which lead human beings to define it in various ways.

The problem of love lies in the fact that it is situated at the level of meaning such that many things can be said about it. The subjects' or persons' experiences vary, thus, creating a problem in meaning. If Lacan was asked about his idea of love, he would probably give an hour of talk ${ }^{5}$ only to say in the end that what he said does not make sense at all. This is because he argues that it "is not possible to say anything meaningful or

to let the other choose one in freedom. In all of these definitions, there is the existence of an other which is the object of love.

${ }^{3}$ Based on Plato's myth of androgyny, which tells the story of human beings once possessing both the male- and the female organ but punished by the gods particularly Zeus, by separating them. Cf. Plato, Symposium, in Collected Dialogues, ed. by Edith Hamilton and Huntington Cairns (NJ: Princeton University Press, 1961), 542-543. This myth has been romanticized and told in different versions resulting perhaps in the idea of the "soul mate." I used this example to emphasize the fact that "love" in its grassroots level is understood in relation to the romantic. And this treatment of love in a fantasized manner has confined it to a certain definition which is limited only to the level of romance.

${ }^{4}$ Lacan strongly links desire with love. According to Dylan Evans, these two concepts are diametrically opposed but they possess characteristics which are similar to each other. The distinction between them becomes more obscure because of Lacan's substitution of one term for another. For instance in his Seminar 8, where he discusses the highlights of Plato's Symposium, he substitutes desire for love. Cf. Dylan Evans, An Introductory Dictionary of Lacanian Psychoanalysis (London and New York: Routledge, 1996), 104. Henceforth will be referred to as $D L P$.

${ }^{5}$ Lacan, however, conducted a whole seminar about love. Moreover, he spoke a great deal about the said topic in his other seminars. Perhaps, he was proving his point that much can be said regarding love, yet there cannot be a single unified meaning which can be attributed to it. According to Dylan Evans in his Dictionary of Psychoanalysis, Lacan wrote a great deal about love for the purpose of demonstrating what the analysand does in psychoanalytic treatment, which according to Lacan himself is "speak about love." The whole process of psychoanalytic treatment, wherein the analyst draws out the knowledge of the analysand and processes his knowledge affect or emotions with the aim of organizing his desires, is already in itself an act of love. Cf. Evans, DLP, 103. 
sensible about love," 6 and "the moment one begins to speak about love, one descends into imbecility." 7 For the post-structuralist Lacan, the meaning of love constantly slips just like all signifiers with their signifieds. He links love to language and discusses it in a manner which is different from those who came before him by saying that "love aims at being, namely at what slips most in language-being that, a moment later, was going to be, or being that, due precisely to having been, gave rise to surprise." 8 Hence, love, being something which has its effect in the symbolic realm or the realm of language, cannot be confined within certain bounds because its object constantly slips. For Lacan, the woman can no longer trust the words of a man who tells her "I love you," because the man might mean something totally different from what he is articulating.

Discussions on love by Lacan can be found everywhere in his works, from the early seminars to the latter ones. Lacan did not write a centralized exposition on love in any of his works although he often talked about them in passing. One of his seminars is entitled Encore: On Feminine Sexuality, The Limits of Love and Knowledge, ${ }^{9}$ but this particular work did not synthesize his notion of love and gave way to more critical questions. Hence, this paper is a humble attempt to discuss the various peculiarities of love, which could be found in some of Lacan's oeuvre.

It is a characteristic of the thinker Jacques Lacan to intertwine the psychoanalytic, the philosophical as well as other disciplines from which he borrows various concepts. Love is not an exemption from this dialogue of disciplines. To be able to understand this thinker's notion of love, I will take into consideration his foundations in psychoanalysis and in the process find out about the philosophical connections of this notion in his work. This exposition, however, does not delve much on the technicalities of the psychoanalytic practice or the clinic. ${ }^{10}$

\footnotetext{
${ }^{6}$ Jacques Lacan, Seminar VIII: On Transference 1960-1961, ed. by Jacques Alain- Miller (Paris: Seuil, 1991), 57.

${ }^{7}$ Jacques Lacan, Seminar XX, 17.

8 Ibid., 39

${ }^{9}$ I am referring to Lacan's published work, The Seminar of Jacques Lacan Book XX Encore, ed. by Jacques Alain-Miller, trans. by Bruce Fink (New York and London: W. W. Norton and Co., 1975).

${ }_{10}$ Psychoanalytic practice is divided into psychoanalytic theory, pertaining to the theoretical part of psychoanalysis, and the psychoanalytic practice, which is referred to in psychoanalysis as the clinic or the actual encounter between the analyst and the patient or analysand.

(c) 2014 Darlene Demandante http://www.kritike.org/journal/issue 14/demandante june2014.pdf

ISSN 1908-7330
} 


\section{Love and the Analytic Discourse}

The universality of love is seen in the fact that it is a notion which has traversed various fields of study. In the psychoanalytic tradition, which was founded by Sigmund Freud, love is understood as an instinctual, libidinal drive towards a love object. Freud calls this the Erotic Instinct or love as Eros. Eros is regarded as one of the two instincts, which accounts for the behavior of human beings. ${ }^{11}$ It is the instinct, which is responsible for the desire of a human being for unity, preservation and for bringing together things, individuals and entities. ${ }^{12}$ Eros is the life instinct, which is also accountable for creation and for the proliferation of life. An example of the effects of this instinct is the process of civilization, which attempts to combine individuals, peoples and nations in one great unity. ${ }^{13}$

Lacan inherited from Freud this notion of love as an erotic drive towards union with the love object. However, rather than emphasizing on the unifying and creative power of love, he emphasized more on the destructiveness of the attachment that love has over the analysand. ${ }^{14}$ In his earliest attempts of the project of "going back to Freud," Lacan stressed much on the problem of love in the psychoanalytic practice and gave emphasis not on its unifying power but instead on the illusion brought about by it with regard to the idea of union between the subject and the object of love. ${ }^{15}$

In this early stage of Lacanian theory, love is regarded as an imaginary passion, an obstacle to analysis because it is based on the idea of

11 The other instinct is the death instinct or Thanatos, which is the opposite of Eros being the force, which makes human beings strive for the inorganic state. It is the drive that moves towards dissolution, disassociation and unbinding. Thus, the death instinct is accountable for whichever may lead to the annihilation of existence. Cf. Pierre Delion, "Thanatos," in International Dictionary of Psychoanalysis. Date Accessed: 10 March 2009, $<$ http://www.enotes.com/psychoanalysis-enctclopedia/eros> accessed.

12 Sigmund Freud, Civilization and Its Discontents, (New York: W.W. Norton \& Company, 1961). 86.

13 Cf. Ernest Wallwork, "Ethics in Psychoanalysis," in American Textbook of Psychoanalysis, ed. by Ethel S. Person, Arnold M. Cooper, Glen O. Gabbard (USA: American Psychiatric Publishing Inc., 2005), 287.

14 The term "analysand" is used to refer to the patient or the subject of psychoanalysis. The subject of psychoanalysis or the Freudian patient is not just any old patient but an analysand or someone who submits to the Freudian technique. Cf. Colet Soler, "The Subject and the Other (I)," in Reading Seminar XI, 41. From this point of the paper, I am going to use the term "subject" and "analysand" interchangeably.

${ }^{15}$ During this period, Lacan reformulated the clinical questions posed by the ego in terms of the rivalry between symmetrical others, the obstacles posed by the three imaginary passions of love, hatred and ignorance. Cf. Veronique Voruz and Bogdan Wolf eds., The Later Lacan: An Introduction (New York: SUNY Press, 2007), viii. 
loving an "other"16 whose image is taken from oneself. It is not really the other that one loves; rather, it is the self in the other. Love is defined in terms of a narcissistic relation to the subject. Lacan argues that love is an illusion of oneness with the beloved and this illusion is carried over in the process of analysis, hindering its success. This is known in psychoanalysis as transference ${ }^{17}$ love.

In the analytic session wherein the analyst interacts with the analysand, certain emotions of the analysand arise and these emotions are projected towards the analyst. The analysand develops a feeling of love for the analyst, wanting to be with the analyst and having the illusions of "falling in love" with the analyst. Thus, the love in this situation is not real in the sense that it is a libidinal drive towards the projected image of the analyst. Transference love is the love that transpires between the analysand and the analyst, wherein the analysand develops love for an image or representation of an other that he sees in the analyst. Lacan believes that this illusion is a reflection of reality, that love is nothing but a misplaced emotion, an emotion brought about by the imaginary ego. Jacques-Alain Miller elaborated on this:

Love in psychoanalysis is transference. The very concept of love, its question of expressions in psychoanalysis is directed by the concept and problematics of transference so that love seems to be only displacement-a case of mistaken identity. Always, I love someone because I'm in love with somebody else. That's why, in analysis, love is slapped with a certain inauthenticity. ${ }^{18}$

16 In Lacanian jargon, "other" is spelled in two different ways to distinguish the imaginary other from the symbolic other. The "other" (small "o") pertains to the other in the imaginary register or the ego which was formed from imaginary identifications as in the mirror stage. The "Other" (capital "O") pertains to the symbolic Other, the structure of language or any structure which initially alienates the subject but with the purpose of organizing the chaotic subject. The "Other" also refers to fellow human subjects whom the subject looks up to for identification.

17 Transference is the process in the psychoanalytic cure, wherein the patient relives or reproduces the past relationships and experiences he/she had with a particular person or persons and projects the affects and emotions to the analyst. Since the goal of analysis is a form of catharsis, in transference, the analysand is made to realize the illusory feelings and misreading of reality that he/she has. Psychoanalysis argues that through this process, the ego achieves a level of maturity and the subject is able to deal with the world and with reality in a better way. Cf. Paul Williams, "What is Psychoanalysis? What is a Psychoanalyst?" in American Textbook of Psychoanalysis, 194.

18 Jacques-Alain Miller, "Love's Labyrinths," ed. by Tom Radigan (Lacanian Ink8 Paris: May, 1992).

(C) 2014 Darlene Demandante

http://www.kritike.org/journal/issue 14/demandante june2014.pdf

ISSN 1908-7330

$(\mathrm{cc}) \mathrm{BY}-\mathrm{NC}$ 
This is tantamount to saying that psychoanalysis in general and transference in particular takes love not as a perfect union of the subject and the object of love but the result of the subject's wrong identification with the analyst. Love is a mistake and, therefore, cannot be treated as an authentic feeling. In the clinical practice of analysis, love is transference, one of the affects $^{19}$ that surface during analysis. Lacan, however, does not totally disregard the positive effects of Eros. He just focuses more on the passionate love, which brings about what he calls "psychological catastrophe" to the subject.

...the question of transference love has from the start been too closely linked with the analytic study of the notion of love. We are not dealing with love in the guise or Eros-the universal presence of a power binding subjects together, underlying the whole of the reality in which analysis is played out-but of passionate love, as it is concretely linked by the subject as a sort of a psychological catastrophe. It raises the question, as you know, of knowing how this passionate love is, in its very essence, linked to the analytic relation. ${ }^{20}$

The love that the subject experiences is a passionate kind of love, which has an adverse effect on its psyche and, in fact, is accountable for its suffering. This very love is also the problem that the analyst wishes to address. By posing love as an affect, Lacan manages to de-center the popular notion of love as a positive feeling and dwells more on its detrimental side. However, more than downgrading the status of love in the life of the subject, the role of the analyst is to help the subject realize the true nature of love and free himself/herself from its affects. Through and through, psychoanalysis is loyal to its therapeutic ideal of curing the patient by clearing him of the affects, which shock his subjectivity.

To summarize, love is one of the imaginary affects that must be confronted and realized so as to achieve a healthier and a more mature ego.

${ }^{19}$ The term "affect" has a technical definition in Lacan's work. It specifically refers to the influence of the symbolic register to the subject; hence, "the subject is affected by his relation with the Other." An affect is usually an emotion or feeling, which is related to the subject in a negative way inasmuch as affect pertains to lures, which can deceive the analyst. Cf. Evans, DLP, 5-6.

${ }^{20}$ Jacques Lacan, The Seminar of Jacques Lacan Book I: Freud's Paper on Technique 19531954, trans. by Jacques Alain-Miller (Cambridge: Cambridge University Press, 1988), 112. 
The subject/analysand must realize that love is a deceptive feeling that should be overcome since it creates a psychological catastrophe within him. If one is to investigate Lacan's notion of love, the first thing to do is to find out its role in the analytic discourse. In psychoanalysis, discussion of love is predominant in relation to transference. Love is taken as transference love. Being this, it is primarily situated in the imaginary register.

\section{Love as Imaginary: Loving Me in the Other}

The very first attempts of Lacan to elucidate on the topic of love can be found in his two earliest seminars, Seminars I and II. At that time, he was working on re-reading, reconstructing and clarifying Freud's thoughts to address some of the most crucial problems of psychoanalysis, such as transference, love and narcissism. Lacan considered these three as imaginary phenomena.

Lacan said "Love is a phenomenon which takes place in the imaginary level...." 21 Love is one of the two features of imaginary relations. Imaginary relations pertain to relationships between egos, wherein everything is played out in terms of sameness and difference. ${ }^{22}$ Love is a feeling of sameness with the other. In the formation of the subject, the other that the subject loves is seen as a wholeness that the subject wants to be the same with. This is tantamount to saying: I often love the one who has the least difference from me because I'm hoping that we could complement each other's lack. On the other hand, I hate the one who is the opposite of me because there is nothing in her or him which could compensate my lack.

Primarily, love is taken as a form of narcissism or self-love. Lacan adopts the Freudian idea of love as narcissistic, wherein the subject loves the other because the subject is able to identify himself or identify with the other. In the realm of the imaginary, love springs from a subject's identification of an ideal ego, which he finds in the image of the other. This ideal ego sums up what the subject desires to achieve, particularly the experience of wholeness. For instance, in the case of children, the love object is the mother because the mother responds to the subject's need for support and nurturing, thus, projecting the image of an other who is in control and complete in itself. In the case of romantic love, the beloved is desired by a lover because of the qualities and traits that he or she exudes and which the subject sees as the ideal. Renata Salecl further describes the situation in the following:

${ }^{21}$ Ibid., 142.

${ }^{22}$ Bruce Fink, The Lacanian Subject: Between Language and Jouissance (New Jersey: Princeton University Press, 1995), 84.

(C) 2014 Darlene Demandante

http://www.kritike.org/journal/issue 14/demandante june2014.pdf

ISSN 1908-7330

(cc) BY-NC 
What is at work in falling in love is the recognition of the narcissistic image that forms from the substance of the ideal ego. When we fall in love, we position the person who is the object of our love in the place of the ideal ego. We love this person because of the perfection we have striven to reach for our own ego. However, it is not only that the subject loves in the other the image he or she would like to inhabit him or herself. ${ }^{23}$

Just as Narcissus fell in love with his image on the water, the subject loves its own image as he sees this image in the other. The subject tends toward the other whom he or she sees as the perfection of himself.

Love as narcissistic does not only mean to love the self and identify something in the other which is similar to me. Narcissism of love also involves posing the self as an object worthy of the love of the other. Thus, love is autoerotic. Love always seeks a response from the other. Moreover, the response that the subject seeks is a response in relation to his very subjectivity. Jacques-Alain Miller says, "We love the one who harbors response or the response to the question 'Who am I?'" 24 In love, what the subject wishes to find and manages to find is about the self. "To really love someone is to believe that by loving them, you'll get to a truth about yourself." 25 This is saying that love is an attempt of the subject to address his original lack.

The imaginary nature of love stems from the subject as a subject of lack. Originally, the subject does not possess anything other than the imaginary identifications of the ego and the symbolic desire to be complete like the other subject, which it perceives as complete. Simply put, the subject is a subject of emptiness. The self is an empty self and to be able to love, one must realize this emptiness or lack within the self. From this, it follows that love is nothing since it is based on a lack. To give love or to love entails that one recognizes the lack in one's being and gives this lack to the Other. Lacan further states:

I have already explained to you how it works by referring to it [as] the narcissistic relation by which the subject becomes an object worthy of love. From his reference to him who must love him, he tries to induce

\footnotetext{
${ }^{23}$ Renata Salecl, Perversions of Love and Hate (London and New York: Verso, 2000), 13.

24 Jacques-Alain Miller, "Jacques Alain Miller: On Love, We love the one who responds to our question Who am I," in The Symptom 10, (1997/2009). Date Accessed: 10 November 2008, <http://www.lacan.com/symptom/?page_id $=263>$.

${ }^{25} \mathrm{Ibid}$.
} 
the other into a mirage relation in which he convinces him of being worthy of love." 26

According to Jacques-Alain Miller, Lacan used to say, "to love is to give what you haven't got." 27 The gift of love is the gift of nothing. Lacan calls love a form of deception, a mirage, a false image of something which is not illusory but imaginary in the sense that one's perception of it is false. Lacan says that, "as a specular mirage, love is essentially deception whose perspective is centered on the ideal point. I place somewhere in the other from which the other sees me, in the form I like to be seen." 28

The need to pose an ideal object of love for the other, a mirage of oneself, stems from the fact that love seeks for a response from the other. However, it is impossible to make this appeal to the other without speech. Love is an imaginary relation, which cannot possibly exist without the symbolic function of language. Therefore, there is no love outside of speech. Love as imaginary is just one facet of love and is considered as the first phase of the subject's encounter with it. The second phase is love in the symbolic register.

\section{Love as Symbolic: I am a Slave of the Other}

Love begins as an imaginary relation but it can hardly be accounted for as love without the symbolic function because it is impossible to love without language. Love only becomes love-that which can be discussed and experienced between subjects-through the symbolic function of language. First and foremost, the reason why emotions can be manipulated, discussed and scrutinized is because there is the symbolic order. In Seminar I, Lacan asserts:

If the emotion can be displaced, inverted, inhibited, if it is engaged in dialectic, it is due to its being taken up into the symbolic order, in accordance with which the other orders, the imaginary and the real, find their place and their disposition. ${ }^{29}$

\footnotetext{
${ }^{26}$ Jacques Lacan, The Seminar of Jacques Lacan Book XI: The Four Fundamental Concepts of Psychoanalysis, ed. By Jacques Alain-Miller, trans. by Alan Sheridan (New York and London: Norton and Company, 1981), 267.

${ }^{27}$ Lacan, Seminar XX, 75.

${ }^{28}$ Lacan, Seminar XI, 68.

${ }^{29}$ Lacan, Seminar I, 239.

(C) 2014 Darlene Demandante http://www.kritike.org/journal/issue 14/demandante june2014.pdf

ISSN 1908-7330

(cc) BY-NC
} 
Lacan argues that everything only makes sense in relation to the symbolic register because it is the organizing structure of reality. There is no love outside of speech and non-speaking beings do not love. Love arises from the subject of the signifier and since a subject of the signifier is a lacking subject, love arises out of the subject from this fundamental split. Therefore, love does not come out from any need but from the original psyche of the subject as split and lacking. ${ }^{30}$

Love is exclusive to speaking beings because only speaking beings are capable of love through speech. "People do not love if they don't talk about love."31 Speech enables the subject to engage the other as he demands for love from this other to be able to fill his lack. It becomes possible to demand from the other since the other is also embedded in the symbolic register. When a woman tells a man that she loves him, two things take place - she is able to let the man know of her feelings of lack and at the same time communicate her desire for a response from the man. This does not solely apply to romantic love but to any other love. What exists in love is a fundamental desire of a subject for the other, which transforms into a demand once it becomes known through language.

Lacan argues that the symbolic has two functions-mediation and revelation. Mediation links the subject to the other in the form of linking the ego with an alter ego. This function is at work whenever the subject seeks a response from the other, "when one addresses the other's ego with seductive intentions or with the intent of making oneself loveable or when one intends to transmit one's feelings, knowledge or experience: one intends to share something." 32 The alter ego is the other as someone who can understand you, who might possibly love you.

Revelation, on the other hand, is the function produced between two subjects, when the subject appeals to other and the other responds. It is called revelation because through this process, the subject which is originally alienated by the ego begins to build a self and reveals this self to the other. The subject wants to make something appear from the Other, and the Other has to make something appear by responding. Notice that the function of mediation links two egos, while revelation, on the other hand, discloses the subject to the Other subject and this other subject in turn reveals itself to the subject. To differentiate between the two others, Lacan

${ }^{30}$ The moment the subject enters the symbolic, he or she is castrated. This split forever remains in him and the life of a subject is a struggle to address this lack. One of the means to fill the void is by way of loving the other, and appealing to the other for a response to one's love.

${ }^{31}$ Renata Salecl, Perversions of Love, 18.

32 Soler, "Transference," 42. 
uses "other" with a small "o" for the subject of the imaginary ego while he uses "Other" with a capital "O" for the subject of the symbolic.

The function of revelation transforms the imaginary love of the ideal ego into the symbolic love of the ego ideal. Lacan also states that without speech, it is impossible to bring love beyond the imaginary. This is because speech is an act and an act is something which has a creative function of bringing something new into the world. ${ }^{33}$ Speech brings about a dynamic character to love so that by means of language, love does not just remain a passive imaginary passion but an active appeal to the other. Lacan said:

I will only remark that love, to the extent that it is one of the three lines of division in which the subject is engaged when he realizes himself symbolically in speech, homes in on the being of the other. Without speech, inasmuch as it affirms being, all there is Verliebtheit, imaginary fascination, but there is no love. There is inflicted love, but not the active gift of love. ${ }^{34}$

The introduction of speech to love makes it possible to differentiate the imaginary fascination between egos in narcissistic love from the ego ideal in love as symbolic. The ideal ego is the product of imaginary identification with the other. It is that which I wish to see in the other. The ego ideal is the symbolic infused Other or the other that I want to see based on symbolic identification. Thus, love as imaginary is love for what a subject wants to see in the other while love as symbolic is the ideal image that the symbolic structure has imbued within the subject. For instance, traits such as kindness, respect and understanding are ideals which have been imposed by the Other to the subject through popular media in the form of fairy tales and stories.

The Ichdeal, the ego-ideal, is the other as speaking, the other insofar as he has a symbolic relation to me [moi], which within the terms of our dynamic manipulation, is both similar to and different from the imaginary libido. Symbolic exchange is what links human beings to each other, that is, it is speech and it makes it possible to identify the subject. That isn't a metaphorthe symbolic begets intelligent beings, as Hegel

${ }^{33}$ Ibid., 47.

${ }^{34}$ Lacan, Seminar I, 276-277.

(C) 2014 Darlene Demandante

http://www.kritike.org/journal/issue 14/demandante june2014.pdf

ISSN 1908-7330

(cc) BY-NC 
says....That is what love is. It's one's own ego that one loves in love, one's own ego made real on the imaginary level..$^{35}$

Speech or the symbolic register puts on a dynamic character to love. It is through language that passive and imaginary love becomes active and moves towards being. Lacan further states:

Now learn to distinguish love as an imaginary passion from the active gift which it constitutes on the symbolic order. Love, the love of person who desires to be loved, is essentially an attempt to capture the other in oneself, in oneself as object.... ${ }^{36}$

Once love is put into speech, it becomes a demand for love, a demand which seeks for satisfaction from the other. The subject seeks to be loved by the other in his specificity and particularities. He desires to be loved for everything that he is and for all the characteristics that he or she possesses. Love becomes an active gift of the subject for the other because it continuously seeks its satisfaction from the other and it never stops demanding from the other. In Seminar XI, Lacan says, "I love you but because I love that which is not in you; I mutilate you." ${ }^{37}$

\section{Lacanian Reading of Plato's Symposium}

In Lacan's theory of love, one finds a merging of the philosophical and the psychoanalytic because among the many of his theories, it is where he refers much to philosophy most particularly that of Plato's. Lacan's Seminar VIII On Transference is a reading of Plato's dialogue on the topic of love, The Symposium. Philosophical influences in Lacan's theory of love can be summarized into two main points. First is that Lacan reads love as transference, portrayed in the case of Socrates and Alcibiades in Plato's Symposium. Secondly, Lacan links love to knowledge and truth, arguing that it is love which brings about the truth of being. Being is not one but two, and there is no such thing as "one."

In Seminar VIII, Lacan supports his psychoanalytic ideas on love through the philosophical dialogues of the characters in Plato's Symposium. For the purpose of this paper, I will not go through them one by one and will only mention those which are essential to the topic at hand. Moreover,

${ }^{35}$ Ibid., 142.

36 Ibid., 276-277.

${ }^{37}$ Lacan, Seminar XI, 263.

(C) 2014 Darlene Demandante http://www.kritike.org/journal/issue 14/demandante june2014.pdf

ISSN 1908-7330 
Seminar VIII is only available in French and I am not adept in the said language. For the reading of the said seminar, I am mainly dependent on Lorenzo Chiesa's article “Le Ressort De L'amour: Lacan's theory of love in his reading of Plato's symposium," 38 which is a reading of Seminar VIII.

Lacan often compares the psychoanalytic method to the Socratic dialogue. He reads the dialogue between Socrates and Alcibiades as one of a transferential relation wherein Socrates is the analyst and Alcibiades is the analysand. To claim that love is a transferential relation leads to the idea that the psychoanalyst regards love as an artificially provoked situation, one laden with falsehood and even a fictional event. While this is true, he proceeds to argue that labeling love as artificial is not to the disadvantage of love but only proves that this psychical fiction is "essential" for the subject.

In Seminar VIII, Lacan comments on the speech of the comedian, Aristophanes. This comedian delivered one of the most striking attacks against the notion of love, an attack against the notion of the "one." Aristophanes began his account of love by telling the story of the existence of human beings as once spherical beings complete in themselves. Aristophanes describes them as having eight limbs and two sets of genitals. However, these beings were ambitious and conceited that Zeus decided to strike them with thunder and separate them into two. From then on, the once spherical beings longed to be together and searched for their half throughout existence. ${ }^{39}$ Aristophanes' speech implies that humans as they are now are inadequate because of the destruction of the sphere and love is a search for the wholeness that human beings once possessed.

From Aristophanes, Lacan gathers that the obvious message is that love is a search for wholeness by finding the one who would fill the gap or lack of a human being. However, Lacan does not take the tragic message of the story and instead proceeds to comment that there is something peculiar about the fact that the most tragic speech in the Symposium was delivered by a comedian. He then commented that, "Aristophanes' speech is nothing but the derision of the Platonic sphairos as it is articulated in the Timaeus." 40 The portrayal of a sphere as a perfect shape is a mockery of the notion of love as perfection. The spherical beings although complete in themselves are not capable of loving other spheres and are confined within themselves; therefore, love itself is lacking and inadequate. There is, in fact, no such thing as the one who could complete the lack of a person because love itself is inadequate.

\footnotetext{
${ }^{38}$ Lorenzo Chiesa, “Le ressort de l'amour: Lacan's Theory of Love in his Reading of Plato's Symposium," in Angelaki: Journal of Theoretical Humanities, 11:3 (2006), 61-81.

39 Plato, The Symposium, ed. by MC Howartston and Frisbee, C.C. Sheffield. (Cambridge: Cambridge University Press, 2008), 22-26.

${ }^{40}$ Lacan, Seminar VIII, 112 in Chiesa "Le ressort de l'amour...," 64.

(C) 2014 Darlene Demandante

http://www.kritike.org/journal/issue 14/demandante june2014.pdf

ISSN 1908-7330
}

$(\mathrm{Cc}) \mathrm{BY}-\mathrm{NC}$ 
The epilogue and the highlight of The Symposium is the speech of Alcibiades in praise of Socrates. Lacan likens the dialogue and the relationship (or the lack of a relationship) between Socrates and Alcibiades to that of a transferential relationship between an analyst and analysand. From the exchange between these two characters, Lacan draws out two main ideas. First is that love springs from a lover's perceptions of the agalma, the object of desire in the beloved. In the case of The Symposium, Alcibiades sees Socrates as someone possessing something, and he desires Socrates because of this hidden invisible thing. Second is that love is a sublimation of desire. Alcibiades in the end realizes that the agalma is present in everyone and not only in Socrates; thus, he stops fearing castration or separation from his beloved Socrates and comes to understand that love is beyond the exclusive desire for an agalma in one person.

In the beginning of the dialogue, Alcibiades joins the drinking party. However, instead of delivering a speech in praise of love as what the original group was doing, he tells the story of how he fell in love with Socrates and tried to seduce the latter but miserably failed in his efforts. Alcibiades likens Socrates to a Silenus, "young and sitting in a sculptor's shop which when opened are found to contain a precious object inside." 41 This hidden object Lacan calls the "object cause of love/desire," and this hidden object is not in anyone or in any specific individual because it is an abstract notion. In Seminar XI, Lacan calls it "object petit a," something which is "in you more than you." 42 However, Alcibiades is not yet enlightened about this matter and sees Socrates as the sole possessor of his object petit a. "He desires Socrates just to make sure that Socrates desires him in return and only him."

Socrates denies the love of Alcibiades and considers himself unworthy of love and tells him that he, Socrates, is nothing. His essence is emptiness and lack. Socrates shows that the other, to whom the subject appeals, is also empty, ${ }^{43}$ that love relies on what the other lacks and not on what the other has. Moreover, Socrates has already gone past the stage of being a smitten, blind lover and has achieved the status of a pure desirer. He has realized that the agalma is nowhere to be found in an individual. Through Socrates' rejection, Alcibiades begins to understand and see things from Socrates' point of view; thus, he agrees when Socrates delivers his interpretation of what Alcibiades said. At the end of the Symposium, Alcibiades becomes like Socrates, a pure desirer.

41 Plato, The Symposium, 53-54.

${ }^{42}$ Lacan, Seminar XI, 293.

${ }^{43}$ Salecl, Perversions of Love and Hate, 28. 


\section{Conclusion: The Truth about the One}

In Seminar XX, Lacan argues that love is linked to the question of truth because of the one. Contrary to the fantasy that love is about being one with the lover or the beloved, Lacan argues that love exposes the truth about the two. Lacan says, "We are but one. Everyone knows of course, that the two have never become but one, but nevertheless 'We are but one.' The idea of love begins with that." 44 This statement is then followed by, "Love, while it is true that it has a relationship with one, never makes anyone leave himself behind...how can there be love for an other." 45 The beginning and the end of love is belief in wholeness. There is the belief that every person is a puzzle which can only be completed by another piece of a puzzle and this puzzle piece is one and exclusive for every person. The missing puzzle piece also makes one person complete and whole.

However, there is no such thing as the one because the truth about the one is that it is an illusion. What persons see as the one is nothing but a mirage of what they want to see based on their self-image. Moreover, there is no such thing as the one because there are many ones. Lacan states:

The One everyone talks about all the time is, first of all a mirage of the One you believe yourself to be. Not to say that that is the whole horizon. There are as many Ones as you like-they are characterized by the fact that none of them resemble any of the others in any way.... ${ }^{46}$

Lacan further argues that it is not the one which arises from love but the two. What is exposed in love is the two, "the enigma of the difference between sexes." 47 Moreover, this unleashing of the two is the proof that love is a non-relation that undoes all relation which believes in the one. Contrary to popular belief, the essence of love is not that of wholeness and harmony but of difference. Lacan even goes to the extent of saying that there is no such thing as love because love only exists to compensate for the lack of a sexual relation. All throughout his works, Lacan insisted on Otherness, arguing that oneness is an impossibility.

Department of Philosophy, University of Santo Tomas, Philippines

\footnotetext{
${ }^{44}$ Lacan, Seminar XX, 47.

${ }^{45} \mathrm{Ibid}$.

${ }^{46}$ Ibid.

${ }^{47}$ Ibid.
}

(C) 2014 Darlene Demandante

http://www.kritike.org/journal/issue 14/demandante june2014.pdf

ISSN 1908-7330

(cc) BY-NC 


\section{References}

Lacan, Jacques, Ecrits: A Selection, trans. by Alan Sheridan (New York: Norton \& Company, 1977). The Seminar of Jacques Lacan Book I: Freud's Paper on Technique

1953-1954, trans. by Jacques Alain-Miller (Cambridge: Cambridge University Press, 1988). The Seminar of Jacques Lacan Book II: The Ego in Freud's

Theory and in the Technique of Psychoanalysis 1954-1955, trans. by Jacques Alain Miller (Cambridge: Cambridge University Press, 1988). The Seminar of Jacques Lacan Book XI: The Four Fundamental Concepts of Psychoanalysis, ed. Jacques Alain-Miller, trans. by Alan Sheridan (New York and London: Norton and Company, 1981). The Seminar of Jacques Lacan Book XX: On Feminine Sexuality The Limits of Love and Knowledge Encore, ed. By Jacques Alain-Miller, trans. by Bruce Fink (New York and London: Norton and Company, 1975).

Chiesa, Lorenzo, Subjectivity and Otherness: A Philosophical Reading of Jacques Lacan, ed. by Slavoj Zizek. (Massachusettes: MIT Press, 2007). "Le Ressort de l'amour: Lacan's Theory of Love in his

reading of Plato's Symposium," in Angelaki: Journal of Theoretical Humanities, 11:3 (2006), <http://kar.kent.ac.uk/8601/1/lacan_plato_angelaki.pdf>.

Delion, Pierre, "Thanatos" in International Dictionary of Psychoanalysis. Date Accessed: 10 March 2009, <http://www.enotes.com/ psychoanalysis-enctclopedia/eros>.

De Kesel, Mark, Eros and Ethics: Reading Jacques Lacan's Seminar VII, trans. by Sigi Jottkand (Albany: State University New York's Press, 2009).

Evans, Dylan, An Introductory Dictionary of Lacanian Psychoanalysis (London and New York: Routledge, 1996).

Feldstein, Richard, Bruce Fink \& Maire Jaanun eds., Reading Seminar XI: Lacan's Four Fundamental Concepts of Psychoanalysis (New York: SUNY Press, 1995). eds., Reading Seminars I and II: Lacan's Return to Freud (New York: SUNY Press, 1996).

Fink, Bruce, The Lacanian Subject: Between Language and Jouissance, (New Jersey: Princeton University Press, 1995).

Freud, Sigmund, Civilization and Its Discontents, ed. by James Strachey (New York: W.W. Norton \& Company, 1961).

Miller, Jacques-Alain, "Jacques Alain Miller: On Love, We love the one who responds to our question Who am I," The Symptom 10, (1997/2009). Dated Accessed: 10 November 2008, <http://www.lacan.com/symptom/ ?page_id $=263>$. 


\section{ON LOVE}

Love's Labyrinths, ed. Tom Radigan (Lacanian Ink8, Paris:

1992). Dated Accessed: 10 March 2009,

$<$ http://www.lacan.com/frame VIII 1.htm>.

Person, Ethel S., M.D., Arnold M. Cooper, M.D., Glen O. Gabbard, M.D. eds., American Textbook of Psychoanalysis (USA: American Psychiatric Publishing Inc., 2005).

Plato, The Symposium, ed. by MC Howartston and Frisbee, C.C. Sheffield (Cambridge: Cambridge University Press, 2008).

Plato, Symposium, in Collected Dialogues, ed. by Edith Hamilton and Huntington Cairns (NJ: Princeton University Press, 1961).

Salecl, Renata, Perversions of Love and Hate (London and New York: Verso, 2000).

Voruz, Veronique, Bogdan Wolf eds., The Later Lacan: An Introduction (New York: SUNY Press, 2007).

Zizek, Slavoj ed., Lacan: The Silent Partners (New York and London: Verso, 2006). 